\title{
Pre-service English Teacher Experience of Using Video-based Descriptive Text Writing During Teaching Practicum: A Narrative Analysis
}

\author{
Danang Muhammad Faisal \\ danangmuhammad3@gmail.com \\ Fauzi Miftakh \\ Fauzi.miftakh@unsika.ac.id

\section{Universitas Singaperbangsa Karawang}

\begin{abstract}
This research aims to find pre-service teacher experience of implementing Video-based Descriptive text during teaching practicum. One insider participant was involved in this research to find his view and perception about the use of video. To process data from participants in the form of selfreflective journals, qualitative methods and thematic analysis are used. This study also presented several other findings, such as emotional and technical problems, social experience, and pedagogical experience. According to this study, when using video-based to teach descriptive writing, participants must put in extra effort, such as making the video interactive and engaging enough for students to watch. Furthermore, the use of video-based has been shown to provide participants with flexibility. One disadvantage of this method is that the teaching process in this way is quite ineffective.
\end{abstract}

Keywords: Pre-service Teacher Experience; Descriptive Writing; VideoBased Learning

\section{INTRODUCTION}

School closure during COVID-19 Because of the pandemic's impact on the learning process at this time, teachers must consider how they will deliver the subject matter with very limited options. Learning activities must change into distance Learning/Online learning which using internet and many other prerequisite tools to establish instructional content, teaching implementation, and program management (Fry, 2001). In the context of language learning, video is one necessary part of a course, it's seen as extremely valuable and important because, along with standard language learning components, it offers learners a thorough understanding of the cultural and social aspects of language use. Recently, the use of learning videos has been widely used, and recently the interest has grown steadily. As a result of emerging ways of online education, video-based learning has emerged, and researchers are now investigating the benefits and drawbacks of online video courses in higher education (Yuan \& Powell, 2013).. Furthermore, it's better to use video created or recorded for distance learning by teachers; taped video-based lessons because it is a straightforward and typically students will like it rather than teacher explaining through long text. 
Writing is one of the language skills that English learners must acquire in addition to listening, speaking, and reading. The subject descriptive writing should use strong sensory descriptions that appeal to the five human senses to illustrate something vividly to the reader which involve: sound, smell, sight, touch, and taste. A description essay should then begin with the main impression of an individual, a location, or an object by the writer, and use spatial order to organize the descriptive writing (Babayigit \& Stainthorp, 2011).

A research about implementation of video-based for learning in classroom has been done several times before with various approach, such as Dwifadjrin \& Pamungkas (2020) who aims to found out the implementation and student response towards the use of video as media in teaching descriptive text; then a research which aims to applying video on writing descriptive text in senior high school was done by Maru et al. (2017); and last is about the effect on YouTube videos toward student's writing descriptive text across student's learning styles was conducted by Felanie (2021). In fact, from several previous research there's still a few research done about the implementation video on the teacher side, and the design was quasi experimental. To fill the gap, this research will find out experience on teacher side, especially pre-service teacher who currently undergo teaching practicum about the implementation video-based on teaching descriptive text during teaching practicum for professional development with narrative inquiry design.

\section{LITERATURE REVIEW}

\section{Previous Related Study}

An aim to find implementation and students' response of video as media in teaching descriptive text done by Dwifadjrin \& Pamungkas (2020). 20 students involved was given questionnaire and observation sheets, the result was students find videos for teaching and learning are effective; students become motivated, highly enthusiasm. However, there still a few students still didn't catch up with learning using video. Maru et al. (2020) done a study with pre-experimental design, the instrument were pre-test and post-test with 26 students involved. It aims to acquire about applying video for writing descriptive text in EFL class. The results are the use of videos are effective and applicable for teaching. Felanie (2021) conducted a study to discover the use of YouTube video towards students' writing descriptive text across learning style. With quasi-experimental design which divided into experimental and control class the result was experimental class score was high than control class, the use of YouTube videos are believed as influencing writing students achievement.

\section{Video-based learning}

One of the most crucial components that a teacher can use to teach is media. Media is used in English language instruction as a tool to assist the teacher in delivering 
materials to learners. According to Mateer et al. (2011), utilizing media engages students, enhances information, drives interest in the subject matter, and highlights the applicability of various topics. Video based learning is one method that involves audio-visual, the use of audio-visual can increase students' attention (Miftakh \& Samsi, 2015). Today, it is reasonably easy to prepare and distribute videos, and this has increased the proportion of videos used in education. This led to many learners have been assisted by video recorded lectures to keep up with their schoolwork (O'Callaghan et al., 2017). Video-based learning is defined as learning process of gaining information, skills, and abilities with the systematic aid of video resources (Giannakos et al., 2016). Unlike traditional textbooks, video lessons are not illustrated in paper, so the major elements can be somewhat difficult to highlight; however, additional details can be presented in video lessons, as well as the visual and audio tips they offer (Pappas et al., 2017).

\section{Descriptive Writing}

The majority of writing research has concentrated on the former; however, writing can be described as a product of transcription and composition (Cragg \& Nation, 2006). Descriptive text can be described as a text that provides details of something or looks, sounds, etc. Writers use a descriptive writing to ensure that their audience is swallowed up in the words on the paper (McLean, 2012). In addition, McLean (2012) clarified that description essays usually use sensory information to describe an individual, a location, or an object. Descriptive writing is a complicated process that requires and integrates a variety of higher and lower-level cognitive abilities, such as oral language, working memory, and transcription skills (Babayigit \& Stainthorp, 2011). In conclusion, descriptive text is a means of perceiving images verbally in speech or writing and arranging them in such a way that the reader can feel the situation being described.

\section{METHOD}

\section{Design and Samples}

The design adopted for this study was narrative inquiry, which was conducted using the qualitative approach. Narrative Inquiry was chosen because the goal of narrative inquiry is to comprehend meaningful human experience (Polkinghorne, 1988). Furthermore, the researcher use self-reflective journal as the data source. The data will be showed in a formed of written narrative instead of statistic number. The site of this research is in one of Senior High School in West Java. The decision to choose this school was because the location is near and reachable from researcher house. The participant of this research is the author of this research which act as insider researcher. Being insider researcher brings author in-depths understand about the issue and tell true experience data (Bonner \& Tolhurst, 2002). 


\section{Instrument and Procedure}

Following observations made at school and prior experience and results obtained during field teaching practice time, the results of these observations were written in the form of self-reflective journals. 8 files total of self-reflective journal is the result of 2 month meeting Furthermore, the self-reflective journal contains the author experiences such as challenges occurred while teaching, author way to teach, reasons why author use recorded video-based to teach descriptive writing, technical problem occurred while teaching, social interaction between teacher and students and sesame peers, and author satisfaction while teaching. The written data then processed using thematic analysis which involved researcher to code the data to generate result.

\section{Data Analysis}

When the data already written in form of self-reflective journal, thematic analysis with semantic approach will be conducted to generate the result. Semantic approach is where coding and theme development reflect the explicit content of the data. The researcher will use Thematic method which said, "it is a way to identify, analyze, organize, describe, and report themes contained in a data set" (Braun \& Clarke, 2006). The stages that Braun and Clarke (2006) made are:

1) Familiarize: The authors familiarize himself with the data before going into coding process. This approach is carried out by reading the author's selfreflective journal several times. Author challenges, technological problems that occurred, pedagogic way of teaching, relationship interaction with teacher and peers, and author satisfaction are all expected to be included in the self-reflective journal.

2) Coding: The coding process involves an activity where the author looks for data in the form of text for interpretation later. The author starts by highlighting the text or sentence that is considered relevant as a topic that refers to experiences and challenges.

3) Generating themes: After the coding process is completed, the author examines the code that has been discovered and searches for patterns that appear frequently. The code that has been discovered can be integrated into a single relevant theme during this phase.

4) Reviewing themes: This phase involves author checking the candidate themes against an existing dataset. The author checks the data repeatedly to make sure the produced data are valid and accurate to be used. In this phase too, authors found a several themes that will be refined, which sometimes involves them being split, merged, or deleted.

5) Defining and naming themes: After completing many finalized lists of topics, the author moves on to defining and naming the theme. The aim is to make author comprehend of what it means, and then assist the author in interpreting the data. Theme's generated during this step are challenges, pedagogies, technical, social aspect and satisfaction researcher. 
6) Producing the report: The last stage is the author writes the data that has been processed. In reporting the data, the author describes the findings, the purpose of the data and how often this theme appears in the data.

\section{RESULT AND DISUSSION}

Thematic analysis and the use of semantic approach will be chosen to generate the data explicitly from self-reflective journal that researcher write during field teaching practice. First the researcher reading all 8 files of self-reflective journal, then performed thematic coding and generated a total of 14 codes. The 14 codes found were then selected and sorted further into more relevant points, some codes that are less relevant are being removed in this process. After the code was revised, the result of the total code was 11 . The 11 revised codes were then divided and sorted into 5 major thematically relevant themes.

Table 1

Thematic Analysis Result of Self-Reflective Journal

\begin{tabular}{|l|c|}
\hline Code & \multirow{2}{*}{ Themes } \\
\hline Feeling nervous & $\begin{array}{c}\text { Teachers' } \\
\text { challenges during } \\
\text { teaching practicum }\end{array}$ \\
\hline Often self-doubt & \\
\hline Having a pressure \\
\cline { 1 - 1 } Having limited resource of \\
material
\end{tabular}

1) Teachers' challenges during teaching practicum: From the participant's first teaching practicum, one of these major issues is actually encountered by preservice teachers during their first teaching practicum, as they frequently perceive themselves to be inadequate and under-trained.

So far, the fourth meeting is going well, but I sometimes still feel excessively nervous before starting to teach. I don't know why, even though I've tried to understand the material to be taught. I am so afraid if I make mistakes in the teaching process. 
This finding is in line with the findings of a study conducted called reality shock by Veenman (1984) and enough to make him feel pressured if students didn't do classroom discipline. Furthermore, teaching practicum challenges do exist as the participant was only given 2 chapters of material and should have split it into 8 weeks of meetings.

It is necessary to know why I have divided this material which is actually quite small in four meetings, this is because the KI/KD and the material provided by cooperating teacher at my school is only limited to 2 materials, namely Kind of Caption and Explanation Text following the PJJ rules issued by the Ministry of Education and Culture.

Time management problems also arise. He did not anticipate this problem beforehand because everything seemed to have been scheduled, but there are things unexpected sometimes.

This teaching process made me a little unable to manage time because at the same time academic workload and KKN were also carried out. Fortunately, KKN doesn't have to go to campus because it's currently covid, but on certain days I have to go to campus to meet with my supervisor maybe about once or twice a week I have to go to campus. Sometimes I also must hold KKN meetings to find out how the process of each division is and what problems it faces and immediately find a solution.

According to Page (2008), discipline has been identified as one of the most common challenges faced by pre-service teachers and is seen as a major issue in most schools.

2) Teachers' Pedagogical Experience during teaching practicum: In an answer to school closure during the Pandemic, he also made recorded video lessons of descriptive writing material to be taught.

During my teaching period, I use video-based learning aids. Every week, I make a video about the material that has been given by my cooperating teacher. The material given is Kind of Caption and Explanation Text. At the second meeting, it was Caption material where I explained dig deeper of what captions are, language features and rules of writing captions. And I present some examples of various types of captions.

The length of the video is important as Doolittle et al. (2015) state that shorter video are more interesting to watch.

I always limit the duration of making videos to only 5-6 minutes, this is done so that children don't get bored easily.

3) Social experience during teaching practicum: Communication and relationship between pre-service teacher and cooperating teacher who gave him an opportunity to teach is a critical part because it will influence the learning outcome Korth \& Baum (2011) and eliminating miscommunication during teaching. 
My cooperating teacher is cooperative and communicative; she helps me a lot in reviewing material and reminds the students to pay attention to what I teach them.

He was very lucky because he got a communicative and helpful cooperating teacher during field teaching practice where she provided him with guidance, moral support, feedback on lesson plans that he made, and gave a book as a resource.

...the cooperating teacher who asked me for teaching materials yesterday gave me feedback, she said that my material was good enough but there were still some things that were lacking. She told me that the material I made only lacked a few examples, the rest were good. Criticisms and suggestions that really help me in the future in making materials.

Furthermore, in terms of sharing ideas with fellow peers or peer mentoring (Wang \& Odel, 2002) who undergo field teaching practice, he always communicates with them and shares what he feels during teaching, asking how they teach, sharing ideas, having mutual support, and reflecting on the material they have taught students.

I quite often ask my friends who are also teaching, we share opinions on how to learn during a pandemic like this. They apparently also did the same thing, namely making the material as simple as possible and not making too many task.

4) Affective/Emotional Experience during teaching practicum: The process of becoming a teacher undoubtedly involves an emotional aspect (Kelchtermans \& Deketelaere, 2016), where things outside of expectations will elicit an emotion, whether pleased or depressing. During field teaching practice for 2 months, participant became emotionally motivated and having enjoyment (Burić and Frenzel, 2019) in teaching which gave him an impact to try make students engaged.

...it turns out that teaching gives me a pleasure to share knowledge with others, there's some satisfying moment when children understand what I have taught, a feeling that cannot be expressed in words.

In addition, he wants the student he taught to keep continue learning although the situation wasn't good and isn't effective at that time. There is a purpose that motivates him to ensure that they continue to study, specifically that their educational needs are met, and he's pleased to share knowledge with them and this is the first step he can contribute as a pre-service teacher to society.

Talking about motivation during teaching, there is one thing that has remained my motivation while being an intern teacher, namely: I have been given the responsibility to teach during a pandemic where students and teachers cannot meet, but not meeting at school is not a good reason to terminate the teaching and learning process. The KBM (Kegiatan Belajar Mengajar) process must continue with all existing limitations so that students' needs for knowledge are still met. 
This is line with previous study by Abonyi et al. (2021) According to the most important factor motivating preservice teachers' decision to pursue teaching as a career is their desire to change the future of children and adolescents while also contributing to society.

\section{CONCLUSION}

The purpose of this study is to find out the experience of myself about using videobased to teach descriptive text. The findings of this narrative analysis shows that $i$ used video-based lessons to teach because meetings with students were limited due to the current pandemic in Indonesia. I put extra effort when creating videomaterials that are should be interactive and engaging enough for students to watch. The video material's short duration is the result of careful consideration and the participants' own experience that videos of very long duration will quickly bore them. The advantage of this video-based lesson is the flexibility it provides for both students and participants, because with video-based material, students can watch it again if they do not feel they understand the material being taught. Participants believe that teaching descriptive writing through video is less effective because participants cannot monitor students in class and students do not receive feedback about their writing from friends. Writing skills cannot be learned just like, because there are rules such as the use of grammar, vocabulary, and involving thinking skills and more rigid, unless they are directly practiced every day in order to increase learning outcome. However, the use of video-based is dependent on two parties because the disadvantages of video-based is that the learning process becomes less effective and didn't give great outcome for student.

\section{REFERENCES}

Abonyi, U. K., Awhireng, D., \& Luguterah, A. W. (2021). Motivations of preservice teachers in the colleges of education in Ghana for choosing teaching as a career. Cogent Education, 8(1). https://doi.org/10.1080/2331186X.2020.1870803

Adedoyin, O. B., \& Soykan, E. (2020). Covid-19 pandemic and online learning: the challenges and opportunities. Interactive Learning Environments. https://doi.org/10.1080/10494820.2020.1813180

Albó, L., Hernández-Leo, D., \& Moreno Oliver, V. (2019). Smartphones or laptops in the collaborative classroom? A study of video-based learning in higher education. Behaviour and Information Technology, 38(6), 637-649. https://doi.org/10.1080/0144929X.2018.1549596

Barkhuizen, G., Benson, P., \& Chik, A. (2014). Narrative Inquiry in Language Teaching. In Routledge.

Bolton, G. (2009). Write to Learn: Reflective Practice Writing. InnovAiT: Education and Inspiration for General Practice, 2(12), 752-754. https://doi.org/10.1093/innovait/inp105

Borg, S. (2018). Teacher evaluation: Global perspectives and their implications for English language teaching: A literature review. British Council, accessed at: 
https://www.teachingenglish.org.uk/article/teacher-evaluation-globalperspectives-their-implications-english-language-teaching

Carmichael, M., Reid, A.-K., Karpicke, J. D., \& Bradley, J. V. (n.d.). www.sagepublishing.com The Current State of Play. https://us.sagepub.com/sites/default/files/hevideolearning.pdf

Doolittle, P. E., Bryant, L. H. and Chittum, J. R. (2015), 'Effects of degree of segmentation and learner disposition on multimedia learning' in Assessing the Impact of Educational Video on Student Engagement, Critical Thinking and Learning: The Current State of Play. https://us.sagepub.com/sites/default/files/hevideolearning.pdf

Harrison, T. (2020). How distance education students perceive the impact of teaching videos on their learning. Open Learning, 35(3), 260-276. https://doi.org/10.1080/02680513.2019.1702518

Hudson, P., Nguyen, T.M.H. \& Hudson, S. (2008). 'Challenges for pre-service EFL teachers entering practicum', paper presented at the 2008 Asia TEFL International Conference "Globalizing Asia: The Role of ELT", Bali, Indonesia, 1-3 August. Available at http://epubs.scu.edu.au/educ_pubs/975/

Indah Sari, Anni Holila Pulungan, \& Rahmad Husein. (2020). Students' Cognition and Attitude in Writing Descriptive Text. Britain International of Linguistics Arts and Education (BIoLAE) Journal, 2(1), 395-404. https://doi.org/10.33258/biolae.v2i1.210

Kelchtermans, G., \& Deketelaere, A. (2016). The emotional dimension in becoming a teacher. In J. Loughran, \& M. L. Hamilton (Eds.), International handbook of teacher education: Volume 2, (pp. 429-461). Springer Singapore. https://doi. org/10.1007/978-981-10-0369-1_13.

Kersting, N. B., Givvin, K. B., Thompson, B. J., Santagata, R., \& Stigler, J. W. (2012). Measuring Usable Knowledge: Teachers' Analyses of Mathematics Classroom Videos Predict Teaching Quality and Student Learning. American Educational Research Journal, 49(3), 568-589. https://doi.org/10.3102/0002831212437853

Koç, E. M. (2011). Development of mentor teacher role inventory. European Journal of Teacher Education, 34(2), 193-208. https://doi.org/10.1080/02619768.2010.539199

Korth, B.B., \& Baum, A.C. (2011). Teachers Supporting Future Teachers: A Critical Part of Early Childhood Teacher Preparation. Young Children, 66, 2026.

Loughran, J., \& Hamil, M. L. (2016). International handbook of teacher education. In International Handbook of Teacher Education: Volume 2. https://doi.org/10.1007/978-981-10-0369-1

Nowell, L. S., Norris, J. M., White, D. E., \& Moules, N. J. (2017). Thematic Analysis: Striving to Meet the Trustworthiness Criteria. International Journal of Qualitative Methods, 16(1), 1-13. https://doi.org/10.1177/1609406917733847

Odo, D. M. (2016). An Investigation of the Development of Pre-Service Teacher Assessment Literacy through Individualized Tutoring and Peer Debriefing. 
Journal of Inquiry and Action in Education, 7(2), 31-61. http://ezproxy.stir.ac.uk/login?url=http://search.ebscohost.com/login.aspx?dir ect $=$ true $\& \mathrm{db}=$ eric $\& A N=E J 1133529 \&$ site $=$ ehost-live

Page, M. L. (2008). You Can't Teach Until Everyone is Listening: Six Simple Steps to Preventing Disorder, Disruption, and General Mayhem. Sage Publishing. https://us.sagepub.com/hi/nam/book/you-can't-teach-until-everyonelistening\#features

Pal, D., \& Patra, S. (2020). University Students' Perception of Video-Based Learning in Times of COVID-19: A TAM/TTF Perspective. International Journal of Human-Computer Interaction, O0(00), 1-19. https://doi.org/10.1080/10447318.2020.1848164

Perry, R. (2004). Teaching Practice for Early Childhood: A Guide for Students (2nd ed.). Routledge. https://doi.org/10.4324/9780203392324

Reeves, T. "The Impact of Media and Technology in Schools A Research Report prepared for The Bertelsmann Foundation." (1998).

Turan, Z., \& Cetintas, H. B. (2020). Investigating university students' adoption of video lessons. Open Learning, 35(2), 122-139. https://doi.org/10.1080/02680513.2019.1691518

Veenman, S. (1984). Perceived Problems of Beginning Teachers. In Review of Educational Research (Vol. 54, Issue 2). https://doi.org/10.3102/00346543054002143

Waddell, M. (1983). The Emotional Experience of Learning and Teaching (I. Salzberger-Wittenberg, G. Williams, \& E. Osborne, Eds.) (1st ed.). Routledge. https://doi.org/10.4324/9780429481611

Wang, P. Y., Chiu, M. C., \& Lee, Y. T. (2020). Effects of video lecture presentation style and questioning strategy on learner flow experience. Innovations in Education and Teaching International, 00(00), 1-11. https://doi.org/10.1080/14703297.2020.1754272

White, C., Easton, P., \& Anderson, C. (2000). Students' Perceived Value of Video in a Multimedia Language Course. Educational Media International, 37(3), 167-175. https://doi.org/10.1080/09523980050184736

Yousef, A. M. F., Chatti, M. A., \& Schroeder, U. (2014). Video-based learning: A critical analysis of the research published in 2003-2013 and future visions. ELmL - International Conference on Mobile, Hybrid, and On-Line Learning, Informatik 9, 112-119.

Zhang, B. (2020). Interrupt to Activate-Transform Passive Video Watching into Engaged Active Learning. College Teaching, $0(0), 1-3$. https://doi.org/10.1080/87567555.2020.1864615

Zhang, D., Zhou, L., Briggs, R. O., \& Nunamaker, J. F. (2006). Instructional video in e-learning: Assessing the impact of interactive video on learning effectiveness. Information and Management, 43(1), 15-27. https://doi.org/10.1016/j.im.2005.01.004 